\title{
LEGAL POSITION OF DOUBLE EMPLOYMENT IN MALAYSIA
}

\author{
Asiah Bidin", Noraida Harun, Kamaliah Salleh, Noor 'Ashikin Hamid \\ Faculty of Law and International Relations, Universiti Sultan Zainal Abidin, 21300 Terengganu, Malaysia \\ asiah@unisza.edu.my* (Asiah Bidin) \\ noraida@unisza.edu.my (Noraida Harun) \\ kamaliahsalleh@unisza.edu.my (Kamaliah Salleh) \\ shikin@unisza.edu.my (Noor ‘Ashikin Hamid)
}

\begin{abstract}
Double employment is a situation where an employee holds double paid jobs, either as an employee or as being self-employed. The issue of double employment has been subject to discussion and even has brought to industrial dispute between employer and employee which require the judicial intervention. While some employers allow their employees to engage in double employment, there are few legislations clearly prohibit this practice. In Malaysia, as to date there is no specific law regulating double employment by employees. This article aims to analyse the position of double employment in Malaysia.
\end{abstract}

Keywords: double employment, fiduciary duty, moonlighting, law, Malaysia

Article Received: 18 October 2020, Revised: 3 November 2020, Accepted: 24 December 2020

\section{Introduction}

Double employment has many terms, including dual employment (Snow \& Abramsom, 1980), multiple jobholding (Betts, 2004) or moonlighting (Md Sabron \& Abu Hassim, 2016). Basically double employment refers to a situation where an employee holds two or more paid jobs, namely primary job and a secondary or additional job simultaneously. An employee might become an employee to more than one employer or he might have one employer and become a self-employed for another job. An employee is said to involve in double employment if he undertakes to hold another job while having a job at the same time repeatedly and continuously not on irregular intervals basis. Stoughton (2017) revealed that law enforcement officers who do job during their offduty are also moonlighting. The number of employees who hold more than one job has increase and become a phenomenon due to several reasons (Kisumano and Wa-Mbaleka, 2017). Sussman (1998) stated that in Canada, this practised is more prevalent among women. Income is believed to be the important factor for finding a secondary employment (Md Sabron \& Abu Hassim, 2016), yet, it is not always the sole reason. Some people may want to have more fulfilment in their lives by doing more daily activities. The literatures suggest that the issue of double employment is rarely addressed. However, certain professionals and several categories of employees have been identified working in two separate jobs. Jeffrery et. al. (2017) reported that in 2015, about 13.5 percent of certified assistant physicians held two or more clinical positions. Evidence showed that it is common for health workers who worked in a public sector to serve in a private sector concurrently (Russo, 2018). Walsh et al. (2015) suggested that some employers choose to hire workers who already have job to work with them. Embracing in more jobs and doing multiple tasks at one time no doubt poses some challenges to an employee as well as to the employer. Md Sabran and Abu Hassim (2016) submitted that moonlighting is not only an issue in Malaysia but in other countries as well. Research suggested that moonlighting contributes to poor performances (Md Sabran and Abu Hassim (2016), job stress (Brown, Sullivan and Maninger, 2015), absenteeism and termination of employees on primary job. It is undeniable fact that some employers may allow their employees to involve in a secondary job, while some may restrict the practice to be performed within the same organisation. Certain countries have laid down specific provisions either allowing or prohibiting 
the practice of double employment, for certain reasons. As far as Malaysia is concerned, as of to date, there is no clear provision regulating the matter. In 2015, the citizens were encouraged to do more jobs in order to earn more to cope with the rising cost of living and it has received many responses from the public (The Star Online, 2015). Despite the lacuna in the legislation, it is believed that some Malaysian employees are practising double employment. Many cases brought before courts need to be settled on the reason that the employee involved in double employment. This paper seeks to look into the issue of double employment in order to analyse its legal position in Malaysian employment legislation.

\section{Objective And Methodology}

The objective of this article is to analyse the legal position of double employment under Malaysian employment law. This article adopts a traditional library search using secondary data from literatures and decided cases. It also involves an analysis on the statutory provisions in the employment legislations including Employment Act 1955, Employees' Social Security Act 1969 and Contracts Act 1950.

3. Law On Double Employment In The United States And India

Double employment provisions have become among the important provisions in a few employment legislations. Some legislations in certain jurisdictions have clearly prescribed the provisions whether permitting or prohibiting double employment to be practised by an employee. United States Census Bureau released a data that about 13 million U.S employees have more than one job, with majority of them are holding two jobs and only 6.9 per cents work in more than two jobs (Beckhusen, 2019). No doubt, the United States have a comprehensive law on double employment. Its Constitution and the provisions in several statutes specifically lay down provisions on the employment of the legislators in other sectors. These provisions may allow or prohibit the legislators to seek other public-sector employment opportunities depending on the provisions of each state. Laws regulating the provisions on double employment are different from one state to another (National Conference of State Legislatures, 2018). It is observed that that law in the United States may allow any employee to work in more than one job without any restrictions. As far as the legislators are concerned, they are allowed to involve in other employment with a condition that any coincident hours of the workday will only be paid once. The legislators are also permitted to hold two jobs as long as they were hired as an employee in another organisation before being elected as a legislator. However, the laws prohibit them from practising double employment if there is conflict in performing their duties. Apart from that, any form of public employment not related to public schools and employment at the state or local levels are not allowed at all.

Indian employment legislations also have specific provisions relating to double employment. The provisions in its labour statutes clearly prohibit double employment to be practised (Pandey, 2016; Venkateshwar, 2018). Factories Act 1948 provides that the employer cannot ask its employee to work more than 9 hours daily (section 51) and more than 48 hours in a week (section 54). Section 60 imposes restriction on the exercise of double employment, which states "No adult worker shall be required or allowed to work in any factory on any day on which he has already been working in any other factory, save in such circumstances as may be prescribed". The section also provides the duration of working hours on employees in factories where the employer is only allowed to impose a normal working hours 9 hours only. Despite having extra hours left daily, an employee is not allowed to work in any other factory or engage with any other employer other than the employer he is working and paid for. Section 65 of the Bombay Shops \& Establishments Act 1948, imposes restriction on the exercise of double employment during holiday or leave. The section states "No employee shall work in any establishment, nor shall any employer knowingly permit an employee to work in any 
establishment, on a day on which the employee is given a holiday or is on leave as per the Act".

The restriction on double employment is also stated in section 9 of the Delhi Shops and Establishments Act 1954, which provides that "No person shall work about the business of an establishment or two or more establishments or an establishment and a factory in excess of the period during which he may be lawfully employed under this Act".

The Shops \& Establishments Acts also provides that if an employee undertakes to serve another establishment while he is still in service with an employer, without seeking permission from his employer, it is to be considered as misconduct and a disciplinary action can be instituted against him even if his services are rendered after working hours of the primary establishment. Normally such provisions are incorporated in the contract of service entered into by the employer and the employee.

Another statute which contains the provision relating to double employment is Central Rules 1956. Item 8 of the Central Rules provides the exclusive service where it states in section 8 " $A$ workman shall not at any time work against the interest of the industrial establishment in which he is employed and shall not take any employment in addition to his job in the establishment, which may adversely affect the interest of his employer".

It is to be observed that the above provision does not clearly prohibit the double employment. However, it imposes certain restriction on the employee not to take up the other employment which is in conflict with the employment he is employed.

Taking the opportunity of another person's employment as well as creating a personal conflict can also be the reasons on prohibiting double employment. Allowing an employee to work in more employments can pose him to a danger due to overworked. The standard working hours daily as accepted by International Labour Organization (ILO) is eight hours. Thus if an employee takes up two or more employments at the same time, he has to spend more time performing his job and thus, can indirectly affect his health. In the case of National
Insurance Co. Ltd. v. P.V. Sheeja \& Ors. (M.F.A. (WCC) No. 59 of 2007), the court held that the employer is liable to give compensation to its employer who died while in the course of employment. A bus driver who died due to heart attack while on the job has been said that his driving job had lead to stress and strain. However, in the case of Gulbahar $v$ Presiding Officer Industrial (CWP No.15088 of 2015), the court rejected the application filled by the employee against unlawful termination since, the employer was able to prove double employment of the employee.

\section{Double Employment Under Malaysian Law}

In 2007, the Malaysia Trades Unions Congress reported that out of 2.1 million its members, about 800,000 engaged themselves in additional job (Malaysian Trades Union Congress, 2007). In 2015, the Deputy Minister (at that time) had suggested Malaysian employees to find another job, but his idea has been rejected and he was criticised for by many parties (The Star, 2015). As of to date, there is no specific law either permitting or prohibiting the practice of double employment in Malaysia. Double employment or moonlighting in Malaysia has become an issue and dispute between an employer and employee which received the attention of the court. The courts in Malaysia explained the rule of 'double employment' from the perspective of agentprincipal relationship. The rule of 'double employment' refers to an act of an agent who accepts another work while he is still an agent to his principal. Double employment is considered as breaching a fiduciary duty of an agent (Dato' See Teow Chuan \& Ors v Ooi Woon Chee \& Ors and other appeals, 2012).

It is a trite law that an employee is considered as an agent to his principal or employer. A normal practice in an organisation is that when an employee accepts an offer to work, the employer shall issue a letter of offer to the employee concerned. Even though the Employment Act 1955 provides that a contract of service can be in writing 
or oral (section 2 of Employment Act 1955), section 10 states that a contract of service for a period more than one month shall be made in writing. Furthermore, there are several implied terms that are used in the contract of service. Though they are not stated in the contract of service, the terms shall bind both employers and employees. Such terms mostly deal with duties and responsibilities of employers and employees. The employee shall always be sincere and faithful towards the employer and cannot put himself in conflict between his personal interest and the interest of his principal. The obligation of an agent is stated in section 168 of Contracts Act 1950 which provides that an agent cannot let his own interest conflict with his duty.

In Dato' See Teow Chuan \& Ors v Ooi Woon Chee \& Ors and other appeals (2012) 6 CLJ 535, court ruled that the company's liquidators are a fiduciary, a trustee, an agent and also an officer of the court. Per Abdul Malik Ishak JCA in delivering the judgment has cited the explanation of Millet LJ in the case of Bristol and West Building Society $v$ Mothew [1998] Ch $1 \mathrm{CA}$ at pp. 18 to 19, who described the conflict of interest and breach of fiduciary duties by saying:

"A fiduciary who acts for two principals with potentially conflicting interests without the informed consent of both is in breach of the obligation of undivided loyalty; he puts himself in a position where his duty to one principal may conflict with his duty to the other: see Clark Boyce v Mouat [1994] 1 A.C. 428 and the cases there cited. This is sometimes described as 'the double employment rule. Breach of the rule automatically constitutes a breach of fiduciary duty”. (para 159 pp. 586).

The rule of 'double employment' has also been cited in the case of Vellasamy Pennusamy \& Ors $v$. Gurbachan Singh Bagawan Singh \& Ors, [2012] 2 CLJ 712 and Desa Mas Enterprise v Chantika Plantation Sdn Bhd [1999] MLJU 387. In both cases the court had refered to the words of Scrutton LJ in the case of Fullwood v. Hurley (1) [1928] 1 KB 498, CA at p. 502:
"No agent who has accepted an employment from one principal can in law accept an engagement inconsistent with his duty to the first principal from a second principal, unless he makes the fullest disclosure to each principal of his interest, and obtains the consent of each principal to the double employment".

An employee is an agent or a fiduciary to his employer. Under a strict rule, double employment is considered as an automatic breach of fiduciary duty where an employee puts himself in a position where his duty to his employer conflict with another employer (Fitzsimons, 2006). Apart from explaining the rule of 'double employment', Most of the Industrial Court used the word moonlighting. In the case of C. Melchers GMBH \& Co. v. Yong Kim Nam [1998] 3 ILR 523, the company had dismissed its employee on the reason of poor performance and that the employee had involved directly in direct selling business for another company. The court held that all the necessary steps have been taken by the employer before dismissing him, therefore the dismissal was valid.

In many instances, the court ruled that an employee who involved in his own business which is similar to the business of his employer is considered as putting himself in a position of conflict of interest, breached of the implied terms of the contract of service and constituted a serious misconduct and the employer was justified in dismissing him from the employment. This can be seen in the case of Mac-Pacific Sdn. Bhd v Din Heng Yew [1998] 3 ILR 577. Since the relationship between the employer and the employee is based on the contract of service, the former can put any term prohibiting the exercise of double employment in the contract. The management is vested with managerial prerogatives to impose any provisions which are deemed necessary in order to run the business effectively and efficiently (Shahrilnizam, Balakrishnan and Murshamshul, 2015). Other than employees, company directors also owe fiduciary duty to protect the company's confidential information (Hassan and Abd Ghadas, 2017). In the case of Cheong Meng Wah \& 2 Perayu lain and My 
Social Network Sdn. Bhd. (Award no 3079 of 2018), the company has stated a restriction on the employee to engage in any other business without prior consent from the employer. Upon discovering that its employees have set up their own ecommerce business while still under the employment with the company, the company gave a show cause letter and later dismissed the employees. The issue to be determined by the court was whether the dismissal was just cause or excuse. After considering the facts of the case, the court ruled that the employees have committed a serious misconduct when incorporating another business while they are employed in the company, and thus their dismissal was just cause or excuse.

In section 7 and 8 or the Employees' Social Security Act 1969 (SOCSO), word employer refers to two categories of employer namely principal employer and immediate employer. Nicholas (2012) describes it as a triangular employment which allows the employee to have more than one category of employer. In other words, impliedly the law recognises the employee to have more than one employer.

\section{Conclusion}

In conclusion it can be said that so far, there is no legal framework on double or multiple employment in Malaysia. While there is a clear prohibition in India, sometimes however, the employee is allowed to engage in another job if he gets prior consent from his employer. However, cases brought before court revealed that the employer was justified in terminating the service of its employee if the employer can show that double employment has caused conflict of interest between the parties and the employee failed to perform his obligations for his first employer. The United States have a very clear legislation on this issue where every state has its own provision either to allow the employee to have double employment with condition or to prohibit it. In the absence of any express legal provision in the statutes on employment, it can be said that the rule governing double employment is based on the permission by the employer. Some employer may put the restriction in the contract of service. On the other hand, if there is no express terms on prohibition to take up more jobs, an employee is bound by the implied terms in the contract of service. Furthermore, based on the agency relationship, the rule of double employment is recognised by court where an employee/ agent must not create conflict with his principal by accepting second job with another principal. However, it is also important to note that in the absence of a clear provision on double employment, Employees' Security Act, 1966 provide provisions pertaining to contribution of SOCSO by multiple employers. It is concluded that an employee who involve in many jobs either on temporary basis, part time job or self-employed is very common in Malaysia. Therefore, there is a need for the government to look into this matter, and perhaps to produce a clear guidelines or policy on double employment as it has its own positive and negative impacts not only on the employer but also on the employee himself. The fact that many cases have been brought Industrial Court as well as court of law, show that the issue of double employment has become an important issue in employment sector.

\section{REFERENCES}

[1] Beckhusen, J. (2019). About 13.M U.S. workers have more than one job. United States Census

Bureau. https://www.census.gov/library/stories/201 9/06/about-thirteen-million-united-statesworkers-have-more-than-one-job.html

[2] Betts, S.C. (2004). Gender Differences in multiple jobholding: Moonlighting among teachers. Journal of Business \& Economic Research.

25-34. https://clutejournals.com/index.php/JBER/ article/download/2908/2956

[3] Brown, S., Sullivan, S.L, Maninger B. (2015). Moonlighting and Morale: The Impact on Educators Who Moonlight and How Classroom Teaching Suffers. The Journal of Multidisciplinary Graduate Research. Vol 1(8). 1-17. http://www.shsu.edu/academics/education/ 
journal-of-multidisciplinary-graduate-

research/documents/2015/Brown-8.pdf

[4] C. Melchers GMBH \& Co. v. Yong Kim Nam [1998] 3 ILR 523.

[5] Cheong Meng Wah \& 2 Perayu lain and My Social Network Sdn. Bhd (Award no. 3079 of 2018)

[6] Dato' See Teow Chuan \& Ors v Ooi Woon Chee \& Ors and other appeals [2012] 6 CLJ 535

[7] Desa Mas Enterprise v Chantika Plantation Sdn Bhd [1999] MLJU 387.

[8] Fitzsimons, M. (2006). Managing pension scheme trustee conflicts of interest. LexisNexis. 4 TL. 211234.https://advance.lexis.com/document/? pdmfid $=1522468 \&$ crid $=2$ fe99d79-a6f34ce7-

$8559964 b 0 c 58237 \mathrm{a} \&$ pdteaserkey $=\mathrm{kb} 5 \mathrm{wk}$ \&pdicsfeatureid $=1517131 \&$ pditab=allpods \&pddocfullpath $=\% 2$ Fshared $\% 2$ Fdocument $\% 2$ Fanalytical-materialsuk\%2Furn\%3AcontentItem\%3A5VBXB6K1-FGCG-S3MM-00000$00 \&$ ecomp $=\mathrm{kb} 5 \mathrm{wk} \&$ earg $=\mathrm{sr} 1 \& \mathrm{prid}=1 \mathrm{a} 7 \mathrm{e}$ 94ec-d44b-47d3-a24c-705eb3b09c5f

[9] https://labour.gov.in/sites/default/files/The FactoriesAct1948.pdf

[10] Hassan, H and Abd Ghadas, Z.A. (2017). Confidentiality of a company information: Challenges for nominee directors. Pertanika J. Soc. Sci. \& Hum. 25(S). 143154.

[11] Human Resources Department, University of California. Dual employment. https://www.hr.ucsb.edu/what-dualemployment.

[12] International Labour Organization. C001 Hours of Work (Industry) Convention, 1919 (No. 1).

https://www.ilo.org/dyn/normlex/en/f?p=N ORMLEXPUB:12100:0::NO::P12100_IL O_CODE:C001

[13] Jeffery, C. et al. (2017). Physician assistant dual employment. Journal of the American Academy of Physician Assistants. 30(7). 35-
38.doi:10.1097/01.JAA.0000515546.6886 0.13

[14] Kisumano, G.M and Mbaleka, S.W. (2017). Moonlighting as a growing phenomenon: A case study of a Congolese Christian University. International Forum. 20(2) 237-253.

[15] Mac-Pacific Sdn. Bhd v Din Heng Yew [1998] 3 ILR 577

[16] Malaysian Trades Union Congress (2007). Report: Many Malaysian officials moonlight to make ends meet. http://www.mtuc.org.my/report-manymalaysian-officials-moonlight-to-makeends-meet/

[17] Md Sabran, M.Z. and Abu Hassim, A. (2016). Moonlighting: Factor affecting job performance among staff at Klang Valley Public Hospital. E-proceeding of the Social Sciences Research (ICSSR 2016). 18-19 July 2016. Kuala Lumpur. https://worldconferences.net/proceedings/i cssr2016/fullpapers/IC\%20148\%20FACT OR\%20AFFECTING\%20JOB\%20PERFO RMANCE\%20AMONG\%20STAFF\%20A T\%20KLANG\%20VALLEY\%20PUBLIC $\% 20$ HOSPITAL.pdf

[18] Ministry of Labour and Employment Government of India. THE FACTORIES ACT, 1948.

[19] National Conference of State Legislatures (2020). Dual Office-Holding Restrictions. https://www.ncsl.org/research/ethics/restri ctions-on-holding-concurrent-office.aspx

[20] National Conference of State Legislatures. (2018). Dual Employment: Regulating Public Jobs for Legislators. https://www.ncsl.org/research/ethics/50state-table-dual-employment.aspx

[21] Nicholas, F.I.X.A. (2012). Dual and multiple employment of insured persons under the Employees' Social Security Act 1969 (Act 4). Paper presented at Holiday Inn Hotel Malacca at the SOCSO Seminar 2012. $19^{\text {th }}-21^{\text {st }}$ October 2012. 
[22] Official Portal Attorney General's Chambers of Malaysia. Contracts Act 1950. http://www.agc.gov.my/agcportal/uploads/ files/Publications/LOM/EN/Act\%20136.p df

[23] Official Portal Attorney General's Chambers of Malaysia. Employees' Social Security $\quad$ Act 1969. http://www.agc.gov.my/agcportal/uploads/ files/Act\%204.pdf

[24] Official Portal Attorney General's Chambers of Malaysia. Employment Act 1955.

http://www.agc.gov.my/agcportal/uploads/ files/Publications/LOM/EN/Act\%20265\% 20-\%20Employment\%20Act\%201955.pdf

[25] Pandey, J. (2016). Dual EmploymentAnalysis of Employment Laws. https://www.linkedin.com/pulse/dualemployment-analysis-laws-jay-pandey

[26] Russo, G., et al. (2018). Understanding nurses' dual practice: A scoping review of what we know and what we still need to ask on nurses holding multiple jobs. Human Resources for Health. 16(14). 1-16.

[27] Shahrilnizam, M, Balakrishnan, P. and Murshamshul, M.K. (2015). Employer's managerial prerogative right: An evaluation of its relevancy to the employer-employee relationship. Pertanika J. Soc. Sci. \& Hum. 23(S). 227-238.

[28] Snow, C. J. \& Abramson, E. M. (1980). By the light of dual employment: Standards for employer regulation of moonlighting. Indiana Law Journal. 55(4). 581-614. https://www.repository.law.indiana.edu/cg $\mathrm{i} /$ viewcontent.cgi? article $=3511 \&$ context $=\mathrm{il}$ j

[29] Stoughton, S.W. (2017). Moonlighting: The private employment of off-duty officers. University Illinois Law Review. 1847-1900.

https://illinoislawreview.org/wpcontent/uploads/2017/10/Stoughton.pdf

[30] Sussman, D. (1998). Moonlighting: A growing way of life. Perspective. 24-31. http://citeseerx.ist.psu.edu/viewdoc/downl oad?doi=10.1.1.499.9481\&rep=rep1\&type $=$ pdf

[31] The Star Online (2015). Deputy Minister's 'two jobs' idea is too much, say Malaysian. https://www.thestar.com.my/news/nation/2 015/12/29/deputy-ministers-two-jobs-ideais-too-much-say-malaysians/.

[32] Vellasamy Pennusamy \& Ors v. Gurbachan Singh Bagawan Singh \& Ors, [2012] 2 CLJ 712

[33] Venkateshwar (2018). Is dual employment allowed in India? Digital Kanoon. http://www.digitalkanoon.com/dualemployment/

[34] Walsh, et al. (2015). Surface-acting outcomes among service employees with two jobs Investigating moderation and mediation effects. Journal of Service Management. 27(4). 534-562. 